\title{
Deleterious Effect of Abamectin on Rat Brain Mitochondria
}

\author{
Reda K. Abdel-Razik and Nadia A. Hamed ${ }^{1}$
}

\begin{abstract}
The neurological damages resulted by abamectin (ABA) poisoning is not completely elucidated, especially in cellular organelles such as mitochondria. In the present study, the pro-oxidant effect of $\mathrm{ABA}$ on rat brain mitochondria was first investigated. A single oral dose of ABA (3.3mg / Kg body weight; $1 / 3 \mathrm{LD}_{50}$ ) was given to rat and the brain mitochondria were isolated at various times (4, 24 and $336 \mathrm{~h}$ ) after dosing. Oxidative stress in this organelle was noticed, since it provokes a significant reduction in the activity of adenosine triphosphatase (ATPase) and superoxide dismutase (SOD) and reduced glutathione (GSH) level. In addition, a significant increase in malondialdehyde (MDA) level was observed in neuronal mitochondria, indicating clearly an intense peroxidation within mitochondria. Second, the histochemical evaluation was carried out to estimate the extent of ischemic brain injury as a result of $\mathrm{ABA}$ exposure. The average area of infarct for the neurologically impaired rats was increased in a time-dependent manner. The percentage of surface area of each infarcted section was found to correlate with the severity of the neurologic deficit. The results suggest that ABA-induced neuronal mitochondrial toxicity may be an important contributing factor to brain aging and neurodegenerative diseases.
\end{abstract}

Keywords: Abamectin toxicity; Antioxidants defence; Brain mitochondria; 2,3,5-triphenyltetrazolium chloride.

\section{INTRODUCTION}

Abamectin (ABA) is a potent endo - and ectoparasitic agent with a broad spectrum of activity in several animal species. It is a fermentation product produced by the actinomycete Streptomycetes avermitilis, (Burg et al., 1979). Abamectin consisting of $\geq 80 \%$ of avermectin $\mathrm{B} 1_{\mathrm{a}}$ and $\leq 20 \%$ avermectin $\mathrm{B} 1_{\mathrm{b}}$ .The mechanism of ABA action is related to its effect on the gamma-aminobutyric acid (GABA) system and $\mathrm{Cl}^{-}$ channels. GABA receptors are responsible for regulating the neural basal tone of the brain (Turner and Schaeffer, 1989) and are in virtually all neurons of the central nervous system (CNS). The symptoms of ABA poisoning exhibited in laboratory animals include pupil dilation, vomiting, convulsions and/or tremors and coma (Lankas and Gordon, 1989).

Mitochondria have been proposed to control cellular energy levels, ATPase is an enzyme present in the inner mitochondrial membrane that is responsible for ATP synthesis driven by the proton electrochemical gradient generated in the respiratory chain .Dysfunction of mitochondrial energy metabolism leads to reduced ATP production, and generation of reactive oxygen species (ROS) such as superoxide anions, hydroxyl radicals and hydrogen peroxide (Cassarino \& Bennett, 1999). ROS are increasingly recognized as playing an important role in neurodegenerative diseases because of their ability to cause oxidative stress and consequently damage cellular contents. Mitochondria constitute the major source of superoxide $\left(\mathrm{O}_{2}{ }^{-}\right)$and other ROS within cells, generating approximately $85 \%$ of total cellular $\left(\mathrm{O}_{2}^{-{ }^{-}}\right)$, via aberrant $\left(\mathrm{O}_{2}\right)$ reactions (Droge, 2002). Inflammatory and histopathological damage were induced by avermectin (AVM) in king pigeon brains were determined by Chen et al., 2013. In addition, the main targeted organelle in nervous system was mitochondria, which indicated that mitochondria may be relevant to the process of inflammation induced by AVM.

Cells are protected against oxidative insults by natural antioxidant products, the brain contains multiple antioxidant defences, of which the mitochondrial manganese-containing superoxide dismutase (Mn-SOD) and reduced glutathione (GSH) seem especially important, oxidative stress develops when the disturbance in balance between the reactive oxygen forms produced in excess, and the factors preventing their harmful effect occur. Toxicity by oxygen radicals has been suggested as a major cause of cancer, aging, heart disease and cellular injury in hepatic and extrahepatic organs (Gram et al., 1986). There is compelling evidence that superoxide dismutases are essential for biological defence against the superoxide anion.

Reduced glutathione (GSH) dependent reactions are clearly of major importance for reducing hydrogen peroxide in mitochondria, not all oxygen used by mitochondria is reduced to water, but a significant fraction of it is converted, apparently through superoxide, to hydrogen peroxide (Forman and Boveris, 1982). Extensive mitochondrial damage when GSH levels are greatly decreased, which demonstrated an important function of GSH. (Martensson et al., 1990).

The brain accounts for less than $2 \%$ of the bodyweight and it consumes $20 \%$ of the basal oxygen uptake. High oxygen consumption is linked to leakage of electrons along the respiratory chain with subsequent

\footnotetext{
${ }^{1}$ Dept. of Mammalian and Aquatic Toxicology, Central Agricultural Pesticides Laboratory (CAPL), Agricultural Research Center (ARC), Alexandria, Egypt

Received November 3, 2015, Accepted December 28, 2015
} 
radical formation. The high amounts of polyunsaturated fatty acids (PUFAs) present in neuronal membranes also contribute to high metabolic rate. Lipid peroxidation is caused by free radicals leading to oxidative destruction of polyunsaturated fatty acids constitutive of cellular membranes. Their destruction leads to the production of toxic and reactive aldehyde metabolites such as malondialdehyde (MDA), this highly cytotoxic metabolite, produced in relatively large amount, can diffuses from its site of origin to attack distant targets and form covalent bonds with various molecules. Also (MDA) caused neuronal mitochondrial dysfunction by directly promoting generation of ROS and modifying mitochondrial proteins (Levent et al., 2006 and Long et al., 2009). Therefore, antioxidant defence parameters include enzymatic antioxidant like superoxide dismutase (SOD), small antioxidant (nonenzymatic) molecules like reduced glutathione (GSH) content and oxidative stress parameter such as lipid peroxide content (MDA) will be examined in our study to determine the effect of abamectin exposure on rat brain mitochondria. Also the extent of brain damage is frequently assessed with the mitochondrial activity indicator 2, 3, 5-triphenyltetrazolium chloride (TTC) which is a histopathologic stain. The TTC, itself is colorless in solution, is reduced by dehydrogenases to yield a red colour (Altman, 1976). Infarcted brain regions do not convert TTC and remain unstained. TTC labeling demonstrates ischemic lesions that can be appreciated visually even without microscopic examination. Infarct areas measured with TTC correspond closely with those measured with other histological methods (Lin et al., 1993).

\section{MATERIALS AND METHODS}

\section{Chemicals}

Abamectin, technical grade (94\%): a mixture containing a minimum of $80 \%$ avermectin $\mathrm{B} 1_{\mathrm{a}}(5-\mathrm{O}-$ demethylavermectin $\mathrm{A}_{\mathrm{a}}$ ) and a maximum of $20 \%$ avermectin $\mathrm{B} 1_{\mathrm{b}}$ (5-O-demethyl-25-de-(1-methylpropyl)25-(1-1 methylethyl) avermectin $A_{a}$ ) was obtained from Agromen Chemicals Co., Ltd. All other chemicals used were of the highest purity grade available from Sigma and Merck Chemical Companies.

\section{Animals}

Adult male albino rats (Sprague-Dawely), Rattus norvegicus albinus, weighting 198 $\pm 5 \mathrm{gm}$ were purchased from Faculty of Medicine; Alexandria University. The animals were allowed to acclimatize under laboratory conditions $\{12 \mathrm{~h}$ light / $12 \mathrm{~h}$ dark, 22$26{ }^{\circ} \mathrm{C}$ temp., 40-70\% humidity $\}$ and provided with commercial diet and water ad libitum for one week before the initiation of the experiment. All maintenance and care were in accordance with the animal welfare guidelines established at the university.

\section{Experimental designs}

Experimental animals were divided into two groups each of fifteen rats.

Group I: received corn oil $1 \mathrm{ml} / \mathrm{kg}$ body weight, used as control. Groups II was received a single oral dose of $3.3 \mathrm{mg} / \mathrm{kg}$ b.w., of abamectin which represent $1 / 3 \mathrm{LD}_{50}$ (the oral median lethal dose $\mathrm{LD}_{50}$ was $10 \mathrm{mg} /$ $\mathrm{kg}$ body weight, Tomlin, 1994). Five animals from each group were scarified at 4, 24 and $336 \mathrm{~h}$ after dosing. The animals were dosed orally via stomach gavage tube. The body weights of control and treated animals were recorded daily. At the end of the tested periods the animals were sacrificed and dissected, and then the brains from both control and treated animals were removed and immediately washed with physiological saline $(0.9 \% \mathrm{NaCl})$, weighed individually and stored at $20^{\circ} \mathrm{C}$ till used.

\section{Isolation of mitochondria}

Rat brain mitochondria were isolated using a slightly modified protocol of Krause et al., 2005. A half brain was homogenized by a $2 \mathrm{ml}$ tight-fit glass Teflon homogenizer with nine strokes after addition of 4 volumes of homogenization buffer ( $320 \mathrm{mM}$ sucrose, 5 $\mathrm{mM}$ Hepes-NaOH, $1 \mathrm{mM}$ EDTA, and $0.5 \mathrm{mM}$ Phenylmethanesulphonyl fluoride (PMSF), $\mathrm{pH} 7.4$ ) to 1 volume of tissue and the homogenate was centrifuged at $1300 \mathrm{~g}\left(4{ }^{\circ} \mathrm{C}, 3 \mathrm{~min}\right)$. The pellet was extracted twice with each 2 and $1 \mathrm{ml}$ homogenization buffer, respectively, and the combined supernatants were centrifuged at $17,000 \mathrm{~g}\left(10 \mathrm{~min}, \quad 4{ }^{\circ} \mathrm{C}\right)$. The mitochondrial pellet was washed once and resuspended in $320 \mathrm{mM}$ sucrose, $0.5 \mathrm{mM}$ PMSF. Isolated mitochondria was frozen as aliquots and stored at -20 ${ }^{\circ} \mathrm{C}$.

\section{Estimation of protein}

The protein content of the mitochondrial preparations was estimated by a method based on that of Gornall et al., 1949.

\section{Biochemical analysis}

\subsection{ATPase activity}

The basic idea of this method is to measure the amount of inorganic phosphate produced from the hydrolytic reaction of ATP by the ATPase, mitochondria (1 $\mathrm{mg}$ protein $/ \mathrm{ml}$ ) were added to a medium containing, $20 \mathrm{mM}$ Tris- $\mathrm{HCl}$, pH 7.6, $5 \mathrm{mM}$ $\mathrm{MgCl}_{2}$ and $5 \mathrm{mM} \mathrm{ATP}$. Then the mixture was incubated for $5 \mathrm{~min}$. at $37^{\circ} \mathrm{C}$ in a shaking water bath. The reaction was stopped by the addition of 5\% trichloroacetic acid (TCA), and then inorganic phosphate (Pi) was determined colorimetrically as described by Taussky 
and Shorr (1953). The intensity of the color was measured spectrophotometrically at $740 \mathrm{~nm}$. The concentration of $\mathrm{Pi}$ was calculated graphically from a standard curve and according to the specific activity was computed as $\mu$ mole $\mathrm{Pi} / \mathrm{mg}$ protein/min. Sensitivity to oligomycin $(1 \mathrm{ug} / \mathrm{ml})$ was tested in all mitochondrial suspensions.

\subsection{SOD activity}

SOD as enzymatic antioxidant was measured spectrophotometrically at $25{ }^{\circ} \mathrm{C}$ by the method of (Marklund and Marklund 1974), with some modifications. The assay medium in a total volume of $1.0 \mathrm{ml}$ containing $50 \mathrm{mM}$ Tris $-\mathrm{HCl}$ buffer $(\mathrm{pH} 8.0)$ and $0.24 \mathrm{mM}$ pyrogallol. Autoxidation of pyrogallol was monitored at $420 \mathrm{~nm}$ for $3 \mathrm{~min}$ in the absence and presence of added enzyme at least three concentrations of the enzyme which produced between 30 to $60 \%$ inhibition of pyrogallol autoxidation were used. One unit of the enzyme activity is defined as the amount which produced $50 \%$ inhibition of pyrogallol autoxidation under the standard assay conditions. Mitochondrial SOD activities were expressed as Units/ mg protein.

\subsection{Reduced GSH content}

GSH content as a nonenzymatic antioxidant was determined according to the method of Beutler et al., (1963). The method based on the reduction of 5, 5, dithiobis (2- nitrobenzoic acid) (DTNB) with glutathione to produce a yellow compound measured at $405 \mathrm{~nm}$, the reduced chromogen directly proportional to GSH concentration. The amount of GSH was expressed as $\mathrm{mg}$ glutathione oxidized/gm. tissue

\subsection{Lipid peroxidation level}

Lipid peroxidation (LPO) was carried out following the procedure of (Ohkawa et al., 1979) using thiobarbituric acid (TBA). Malondialdehyde (MDA) formed as an end product of peroxidation of lipids, served as an index of the intensity of oxidative stress. MDA reacts with TBA to generate a colored product that absorbs at $532 \mathrm{~nm}$. The level of lipid peroxides was expressed as nmoles of MDA released/ $\mathrm{mg}$ protein.

\section{Histological evaluation}

The extent of brain infarction after treatment with abamectin is frequently assessed with the mitochondrial activity indicator 2, 3, 5-triphenyltetrazolium chloride (TTC) according to Bederson et al., 1986. Individual slices (at about 1-3 mm thick) were soaked for 20 minutes in a solution of $1 \%$ TTC in $0.2 \mathrm{M}$ phosphate buffer, $\mathrm{pH} 7.4$, at $37^{\circ} \mathrm{C}$ in a water bath. Gentle stirring of the slices ensured even exposure of the surfaces to staining. Excess TTC was then drained, and slices were fixed in $4 \%$ phosphate-buffered formalin for photography. Tracings of Infarcted areas were made from the photographs and quantified by an imaging analysis system (Image $\mathbf{J}$ software program). Total brain and infarct areas were automatically determined on the basis of total pixel intensity and area after segmentation of the red and green images, respectively. The statistical significance of differences in infarct size, expressed as a percentage of infarcted area to total brain area.

\section{Statistical analysis}

Data obtained from the experiments were expressed as mean \pm standard deviation (SD). Significant differences of measurement traits were analyzed using one-way analysis of variance (ANOVA) followed by the Student-Newman-Keuls Test. The criterion for statistical significance was set at $p<0.05$. These test were performed using a computer software CoStat program.

\section{RESULTS}

\section{Biochemical studies}

The in vivo effects of the single dose of one third $\mathrm{LD}_{50} \mathrm{ABA}$ on ATPase and SOD activities and GSH and MDA contents in rat brain mitochondria were summarized in Tables $1 \& 2$.

\section{ATPase activity:}

A significant reduction in the ATPase activity of rat brain mitochondria was observed after 4 and $24 \mathrm{~h}$ of ABA treatment by 17.1 and $10.2 \%$, respectively compared to the control. This effect became less dramatic and returned to the normal value after $336 \mathrm{~h}$ (Table 1).

\section{SOD activity:}

ABA significantly decreased the activity of SOD at all tested time intervals $(4,24$ and 336 h by 77,84 and $83.9 \%$, respectively compared to control (Table 1 ).

Table 1. ATPase and SOD activities in rat brain mitochondria after various time of treatment with a single sublethal dose of abamectin $(3.3 \mathrm{mg} / \mathrm{Kg}$ body weight)

\begin{tabular}{ccc}
\hline & \multicolumn{2}{c}{ Enzyme activity } \\
\hline $\begin{array}{c}\text { Treatment } \\
(\mathbf{h r})\end{array}$ & $\begin{array}{c}\text { ATPase } \\
(\boldsymbol{\mu m o l ~ P i} / \mathbf{m g} \\
\text { Protein / min.) }\end{array}$ & $\begin{array}{c}\text { SOD } \\
(\mathbf{U} / \mathbf{m g} \text { Protein) }\end{array}$ \\
\hline 0 & $29.82 \pm 0.23^{\mathrm{c}}$ & $67.67 \pm 1.46^{\mathrm{c}}$ \\
\hline 4 & $24.73 \pm 0.43^{\mathrm{a}}$ & $15.5 \pm 0.10^{\mathrm{b}}$ \\
\hline 24 & $26.79 \pm 0.26^{\mathrm{b}}$ & $10.8 \pm 0.12^{\mathrm{a}}$ \\
\hline 336 & $29.48 \pm 0.50^{\mathrm{c}}$ & $10.87 \pm 0.12^{\mathrm{a}}$ \\
\hline
\end{tabular}

Values are expressed as means (5 rats) \pm standard deviation (SD)

Values in column with different letters are significantly different at $(\mathrm{p}<0.05)$. 
Table 2. GSH and MDA contents in rat brain mitochondria after various time of treatment with a single sublethal dose of abamectin (3.3 mg / Kg body weight).

\begin{tabular}{ccc}
\hline $\begin{array}{c}\text { Treatment } \\
\text { (hr) }\end{array}$ & $\begin{array}{c}\text { GSH } \\
\text { ( } \begin{array}{c}\text { Pmol } / \mathbf{m g} \\
\text { Protein) }\end{array}\end{array}$ & $\begin{array}{c}\text { MDA } \\
\text { (nmol / mg } \\
\text { Protein) }\end{array}$ \\
\hline 0 & $15.64 \pm 0.41^{\mathrm{c}}$ & $3.06 \pm 0.015^{\mathrm{a}}$ \\
\hline 4 & $11.88 \pm 0.16^{\mathrm{b}}$ & $3.33 \pm 0.12^{\mathrm{a}}$ \\
\hline 24 & $11.63 \pm 0.25^{\mathrm{b}}$ & $5.73 \pm 0.09^{\mathrm{b}}$ \\
\hline 336 & $10.8 \pm 0.20^{\mathrm{a}}$ & $7.03 \pm 0.09^{\mathrm{c}}$ \\
\hline
\end{tabular}

Values are expressed as means (5 rats) \pm standard deviation (SD)

Values in column with different letters are significantly different at $(\mathrm{p}<0.05)$.

\section{Reduced GSH content:}

GSH content of rat brain treated with ABA was significantly decreased in a time dependent manner (4, 24 and $336 \mathrm{~h}$ ) by $24.04,25.64$ and $30.94 \%$ respectively as compared to the control (Table 2).

Malondialdehyde (MDA) content:

Malondialdehyde (MDA), the last product of lipid peroxidation caused by oxidative stress. Abamectin resulted in a significant elevation at 24 and $336 \mathrm{~h}$ by $8.82,87.25$ and $129.74 \%$, respectively with respect to control (Table 2).

\section{Histological evaluation:}

The TTC stained normal tissue in red while the infarcted or ischemic tissue remained unstained (Fig.1). Our results demonstrated complete staining in the brains of control group. The size of infarction area in the brains of the treated group was significantly increased in a time-dependent manner. In 4 and $24 \mathrm{hr}$ the border between stained and unstained areas was well-defined and could be detected easily. While at $336 \mathrm{~h}$, the red color of stained sections almost disappeared. The percentages of infarcted area to total brain area were 55, 63 and $78 \%$ at 4,24 and 336 h, respectively.

Table 3. Infarction area determined by TTC as a percentage of brain section after various time of treatment with a single sublethal dose of abamectin (3.3 mg / Kg body weight)

\begin{tabular}{lc}
\hline Treatment (hr.) & Infarcted area (\%) \\
\hline 0 & $0^{\mathrm{a}}$ \\
\hline 4 & $55.07 \pm 1.50^{\mathrm{b}}$ \\
\hline 24 & $63.78 \pm 1.22^{\mathrm{c}}$ \\
\hline 336 & $78.13 \pm 1.56^{\mathrm{d}}$ \\
\hline
\end{tabular}

Values are expressed as percentage of infarcted area to total brain area (5 sections of each rat) \pm standard deviation (SD)

Values in column with different letters are significantly different at $(\mathrm{p}<0.05)$.

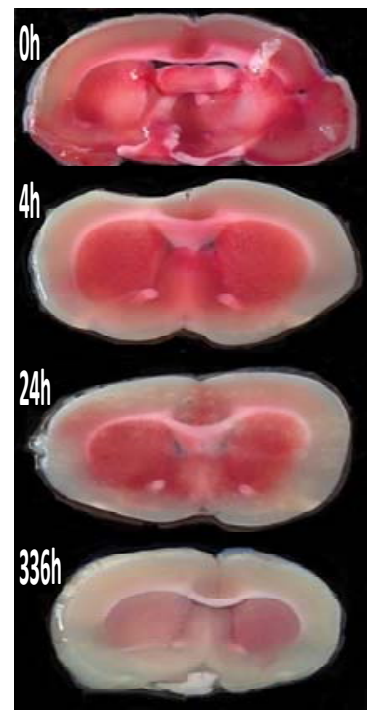

Fig.1. Rat brain sections stained by TTC after various time of treatment with a single sublethal dose of abamectin ( $3.3 \mathrm{mg} / \mathrm{Kg}$ body weight).

\section{Discussion}

Regulation of redox balance is essential throughout life, and dysfunction in the mechanisms underlying the redox balance is believed to be involved in various disease states, including neurodegeneration. Accumulating evidence suggests that impaired mitochondrial energy production and increased mitochondrial oxidative damage are early pathological events that lead to neurodegeneration (Beal, 1996).

ATPase plays an important role in the maintenance of cell permeability and energy transformation in the biological system. Its activity can be taken as a meaningful index of cellular activity and forms a useful toxicological tool (Sushma and Rao, 2007). Data showed that the activity of the brain ATPase was significantly inhibited in the early times then recovered at $336 \mathrm{~h}$ compared to control group. The inhibition of ATPase leads to reduced ATP production, and generation of reactive oxygen species (ROS). In line with other studies stated that some pesticides alter the $\mathrm{Mg}^{2+}$-ATPase which may be a causative factor of neuronal / cellular dysfunction (Mehta et al., 2005 and Rahman et al., 2000).

Maioli et al., 2013 demonstrated that ABA inhibited the activity of ATPase and adenine nucleotide translocator (ANT) when added at micromolar concentrations to isolated rat liver mitochondria, which was associated with significantly reduced ATP synthesis.

Superoxide $\left(\mathrm{O}_{2}^{-{ }^{-}}\right)$; one of the reactive oxygen species (ROS) generated by mitochondrial respiration, 
is involved in a variety of biological processes in central nervous system (Maier and Chan, 2002). The superoxide dismutases $\left(\mathrm{SOD}_{\mathrm{s}}\right)$ are enzymes that catalyze the conversion of $\mathrm{O}_{2}{ }^{--}$, play a primary role in neuronal apoptosis to hydrogen peroxide $\left(\mathrm{H}_{2} \mathrm{O}_{2}\right)$ and help prevent the build-up of toxic $\mathrm{O}_{2}{ }^{--}$. In the present study it was found that ABA diminished activity of SOD in rat brain mitochondria .This result was agreed with (Wheeler et al., 2001) who found that, decrease of mitochondrial SOD by about $50 \%$ resulted in a functional decline of oxidative phosphorylation, an increase in oxidative stress and an increase in the rate of apoptosis. This data suggests that SOD plays an important role for balances of mitochondria redox status.

Reduced GSH is important for reducing hydrogen peroxide in mitochondria. It is present at high concentrations within the brain and its intracellular equilibrium has been shown to be important for health and function of brain cells (Dringen, 2000). Obtained results revealed significant reduction in brain mitochondrial GSH content, it can be assumed that the reduction in glutathione levels was as a result of increased oxidative stress occasioned by the ABA treatment, which in a accordance with Schulz et al., 2000 who reported that GSH is involved in nullifying the toxic effect of ROS in neuronal cells and its depletion leads to increased apoptotic signalling and consequent neuronal death. Various in vitro and in vivo studies have evidenced a neuroprotective role of GSH against a wide variety of oxidative insults (Dringen and Hirrlinger, 2003). Reduced mitochondria GSH levels lead to $\mathrm{H}_{2} \mathrm{O}_{2}$ accumulation that can cause lipid peroxidation and cell injury (Martin et al., 2000).

Brain is highly susceptible organ to peroxidative damage because of its high degree of unsaturated fatty acids in relation to its antioxidant levels and its high oxygen consumption (Braughler, 1989). MDA caused neuronal mitochondrial dysfunction by directly promoting generation of ROS and modifying mitochondrial proteins and this may be an important contributing factor to brain aging and neurodegenerative diseases. Therefore, recognition of lipid peroxidation is of interest, as the deleterious effects of this process. Our data exhibited a significant elevation of MDA content due to ABA exposure which clearly indicated the deterioration of structural and functional integrity of neuronal mitochondrial membrane. Weighand et al., 1999 reported the elevated MDA levels as one of the major mechanisms of secondary damage in traumatic brain injury. Generation of oxidative stress and consequent lipid peroxidation by pesticides was also reported in rat and human brain (Verma and Srivastava, 2003).
TTC is one of the histochemical staining methods for identification of infarcted tissue (Altman, 1976). In the present study the histochemical examination showed some necrotic changes in the brain tissues due to lacking in dehydrogenases activity reflect an irreversible brain ischemic damage which in agreement with Kloner et al., 1981, and this supported by the above findings about the deleterious effect of $\mathrm{ABA}$ on the brain mitochondria.

\section{CONCLUSIONS}

Changes in the bioenergetic and antioxidant defence parameters, in addition to the histochemical evaluation in the present study indicated an adverse effect of ABA on mammal's brain.

\section{REFERENCES}

Altman, F.P.1976.Tetrazolium salts and formazans. Prog. Histochem. Cytochem. 9:1-56.

Beal, M.F. 1996. Mitochondria, free radicals, and neurodegeneration. Curr. Opin. Neurobio 6: 661-666.

Bederson, J.B., Pitts, L.H., Germano, S.M., Nishimura, M.C., Davis, R.L. and Bartkowski, H.M. 1986.Evaluation of 2,3,5-triphenyltetrazolium chloride as a stain for detection and quantification of experimental cerebral infarction in rats. Stroke 17:1304-1308.

Beutler, E., Duron, O. and Kellin, B.M.1963. Improved method for the determination of blood glutathione. J. Lab. Clin. Med. 61: 882-888.

Braughler, J.M.1989. Central nervous system trauma and stroke, Biochemical consideration for oxygen radicals formation and lipid peroxidation. Free Radical Bio. Med. 6: 289-301.

Burg, R.W., Miller, B.M., Baker, E.E., Birnbaum, J., Currie, S.A., Hartman, R., Kong, Y.L., Monaghan, R.L., Olson, G., Putter, I., Tunac, J.B., Wallick, H., Stapley, E.O., Oiwa, R.and Omura, S. 1979. Avermectins, new family of potent anthelmintic agents: producting organism and fermentation. Antimicrob. Agents Chemother. 15: 361367.

Cassarino, D.S.and Bennett, J.P. 1999. An evaluation of the role of mitochondria in neurodegenerative diseases: mitochondrial mutations and oxidative pathology, protective nuclear responses, and cell death in neurodegeneration. Brain Res. Rev. 29: 1-25.

Chen, J.P., Xu, S. and Li, S. 2013. Avermectin induced inflammation damage in king pigeon brain. Chemosphere 93: 2528-2534.

Dringen, R.2000. Metabolism and functions of glutathione in brain. Prog. Neurobiol. 62: 649-671.

Dringen, R. and Hirrlinger, J. 2003 Glutathione pathways in the brain. Biol. Chem. 384: 505-516.

Droge, W. 2002. Free radicals in the physiological control of cell function. Physiol. Rev. 82, 47-95. 
Forman, H.J. and Boveris, A. 1982. In Free Radicals in Biology, ed. Pryor, W. A. (Academic, New York), Vol. 5, pp. 65-90.

Gornall, A.G. Bardawill, C.J. and David, M.M. 1949. Total protein was determined spectrophotometerically. J. Biol. Chem.177:751-766.

Gram, T.E., Okine, L.K. and Gram, R.A. 1986. The metabolism of xenobiotics by certain extrahepatic organs and its relation to toxicity. Annu. Rev. Pharmacol. Toxicol. 26: 259-291.

Kloner, R.A., Darsee, J.R., DeBoer, L.W.V.and Carlson, N. 1981. Early pathological detection of acute myocardial infarction. Arch. Pathol. Lab. Med.105: 403-406.

Krause, F., Reifschneider, N.H., Goto, S. and Dencher, N.A. 2005. Active oligomeric ATP synthases in mammalian mitochondria. Biochem. Biophys. Res. Commun. 329: 583-590.

Lankas, G.R. and Gordon, L.R.1989. Toxicology In: Campbell, W.C. (Ed.), Ivermectin and Abamectin. Springer-Verlag, New York, pp. 102-107.

Levent, G., Ali, A., Ahmet, A., Polat, E., Aytac, C. Ayse, E. and Ahmet, S. 2006. Oxidative stress and antioxidant defense in patients with chronic hepatitis $\mathrm{C}$ patients before and after pegylated interferon alfa- $2 \mathrm{~b}$ plus ribavirin therapy. J of Trans. Med. 4:25-31.

Lin, T.N., He, Y.Y., Wu, G., Khan, M., Hsu, C.Y.1993. Effect of brain edema on infarct volume in a focal cerebral ischemia model in rats. Stroke 24:117-121.

Long, J., Liu, C. Sun, L., Gao, H., Liu, J. 2009. Neuronal mitochondrial toxicity of malondialdehyde:Inhibitory effects on respiratory function and enzyme activities in rat brain mitochondria.Neurochem. Res. 34:786-794.

Maier, C. M. and Chan, P. H. 2002. Role of superoxide dismutase in oxidative damage and neurodegenerative disorders.Neurosci.8: 323-334.

Maioli, M.A., deMedeiros, H.C.D., Guelfi , M., Trinca, V.,Pereira, F.T.V. and. Mingatto, F.E. 2013. The role of mitochondria and biotransformation in abamectin-induced cytotoxicity in isolated rat hepatocytes.Toxicol. in Vitro 27: 570-579.

Marklund, S. and Marklund, G. 1974. Involvement of the superoxide anion radical in the autoxidation of pyrogallol and a convenient assay for superoxide dismutase. Eur. J. Biochem. 47:469-474.
Martensson, J., Jain, A. and Meister, A. 1990. Glutathione is required for intestinal function .Proc. Nail. Acad.Sci. USA. 87: 1715-1719.

Martin, M., Macias, M., Escames, G., Leon, J. and Acunacastroviejo, D. 2000. Melatonin but not vitamins C and E maintains glutathione homeostasis in tert-butyl hydroperoxide induced mitochondrial oxidative stress. FASEB J. 14:1677-1679.

Mehta, A., Verma, R.S. and Srivastava, N. 2005. Chlorpyrifos-induced alterations in rat brain acetylcholinesterase, lipid peroxidation and ATPases. Indian J. Biochem. Biophys. 42:54-58.

Ohkawa, H., Ohishi, N., Yagi, K. 1979. Assay of lipid peroxides in animal tissues by thiobarbituric acid reaction. Anal. Biochem. 95: 351-358.

Rahman, M.F., Siddiqui, M.K.J. and Jamil, K. 2000. Inhibition of acetylcholinesterase and different ATPases by a novel phosphorothionate (RPR-II) in rat brain. Ecotoxicol. Environ.Safty 47: 125-129.

Schulz, J.B., Lindenau, J., Seyfried, J. and Dichgans, J.2000. Glutathione oxidative stress and neurodegeneration. Eur. J. Biochem. 267: 4904-4911.

Sushma, N.J.and Rao, K.J. 2007.Total ATPases activity in different tissues of albino mice exposed to aluminium acetate. Environ. Biol. 28:483-484.

Taussky, H.H. and Shorr, E. With the technical assistance.1953. Amicrocolorimetric method for the determination of inorganic phosphorus. J. Biol. Chem. 253: 956-964.

Tomlin, CDS. (1994). The Pesticide Manual - World Compendium. $10^{\text {th }}$ ed. Surrey, UK: The British Crop Protection Council. p. 4 **PEER REVIEWED**

Turner, M.J., Schaeffer, J.M. 1989. Mode of action of ivermectin. In: Campbell, W.C. (Ed.), Ivermectin and Abamectin. Springer Verlag, New York, pp. 73-88.

Verma, R.S. and Srivastava, N. 2003. Effect of chloropyrifos on thiobarbituric acid reactive substances,scanenging enzymes and glutathione in rat tissues. Indian J. Biochem. Biophys. 40: 423-428.

Weighand, M.A., Laipple, A. and Plascke, K.1999. Concentration changes of malondialdehyde across the cerebral vascular bed and shedding of L-selection during carolide endartereomy. Stroke 30:306-311.

Wheeler, M.D., Nakgami, M., Bradford, B.U., Uesugi T., Mason, R.P., Connor, H.D., Dikalowa, A., Kadiiska, M. and Thurman, R.G. 2001. Overexpression of mangenase superoxide dismutase prevents alkohol-induced liver injury in the rat. J. Biol. Chem. 276: 36664-36672. 


\section{الملهص العري \\ التأثيرك الضارة للألبامكنين عل ميتوكوندربامخ الفئرل}

رضا خمبيس عبد الرازق، ناية على حلمد

سيسميوتيز(SOD) والجلوتاثيون المختزل (GSH) بالاض الفة

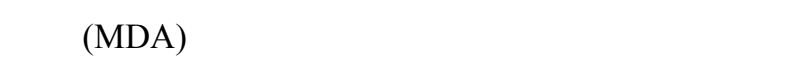

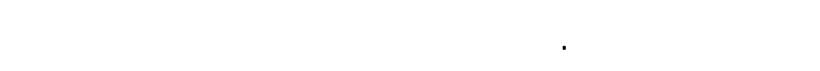

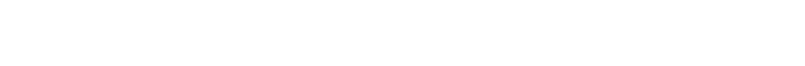

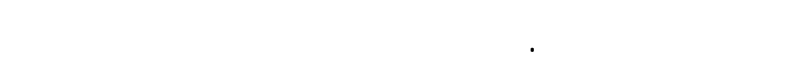

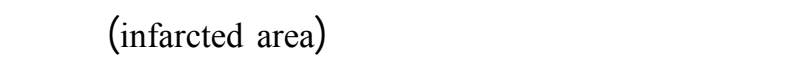
مع الزمن. والنسبة المئوية المسلحة فطحح الفطاع المتضرر المشخر

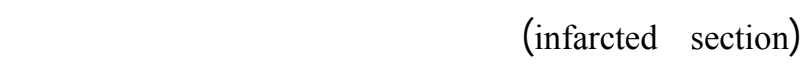
الحادث. ونستخلص من النتائج ان الأبلمكتين لحدث المس مية المين

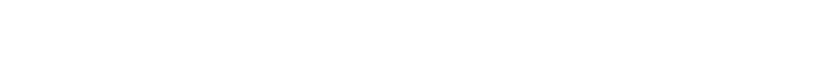
لمشيخوخة المخ والمراض العصبية المتدهورة.
الأضرار العصبية الناتجة عن التسم بالأب لمكتين لـ م

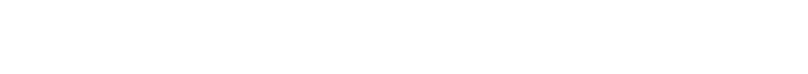

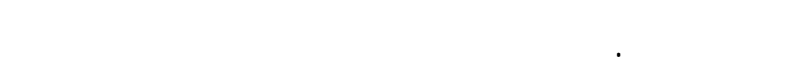

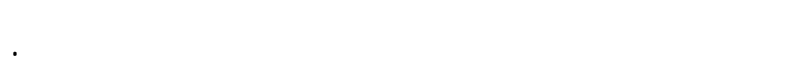

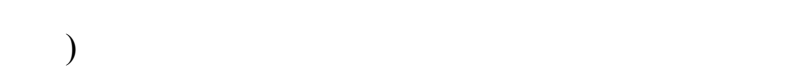

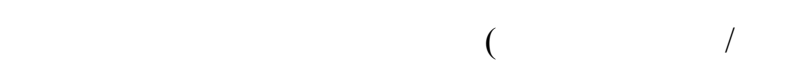

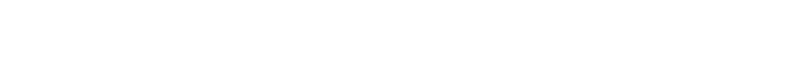

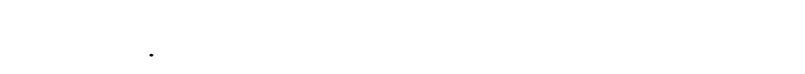

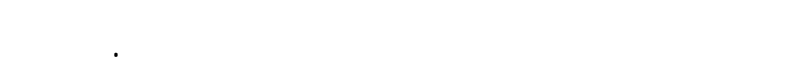
حدث النخفاض فى نشط كلامن منتج الفوسفلت اديذ -وزين

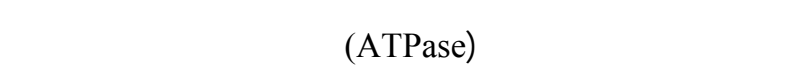

